
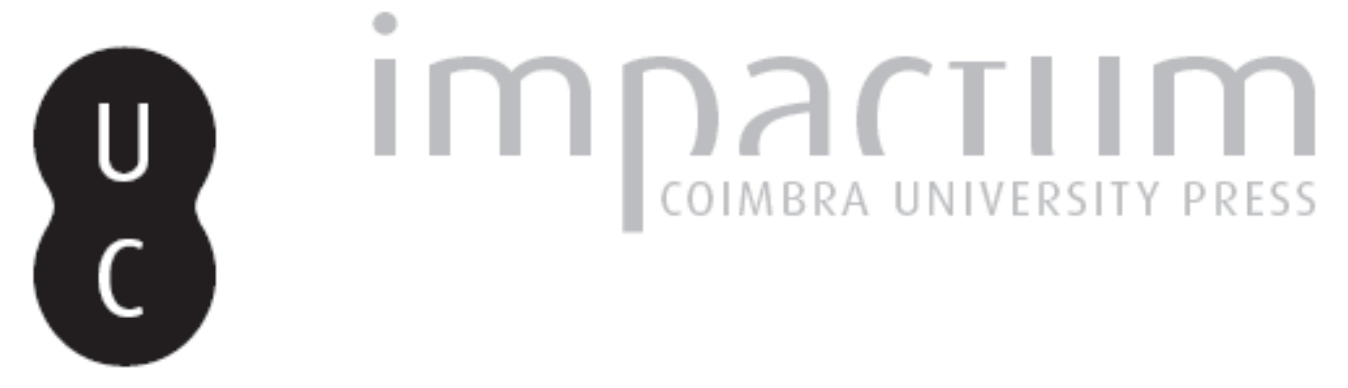

\title{
New evidence for the completeness of the Cleitophon from Plato's musical symbolism
}

\author{
Autor(es): Kennedy, Jay
}

Publicado por: Sociedade Brasileira de Estudos Clássicos

URL persistente:

URI:http://hdl.handle.net/10316.2/35786

DOI:

DOI:http://dx.doi.org/10.14195/2176-6436_23_1

Accessed : $\quad$ 26-Apr-2023 06:29:10

A navegação consulta e descarregamento dos títulos inseridos nas Bibliotecas Digitais UC Digitalis, UC Pombalina e UC Impactum, pressupõem a aceitação plena e sem reservas dos Termos e Condições de Uso destas Bibliotecas Digitais, disponíveis em https://digitalis.uc.pt/pt-pt/termos.

Conforme exposto nos referidos Termos e Condições de Uso, o descarregamento de títulos de acesso restrito requer uma licença válida de autorização devendo o utilizador aceder ao(s) documento(s) a partir de um endereço de IP da instituição detentora da supramencionada licença.

Ao utilizador é apenas permitido o descarregamento para uso pessoal, pelo que o emprego do(s) título(s) descarregado(s) para outro fim, designadamente comercial, carece de autorização do respetivo autor ou editor da obra.

Na medida em que todas as obras da UC Digitalis se encontram protegidas pelo Código do Direito de Autor e Direitos Conexos e demais legislação aplicável, toda a cópia, parcial ou total, deste documento, nos casos em que é legalmente admitida, deverá conter ou fazer-se acompanhar por este aviso.

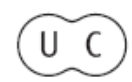




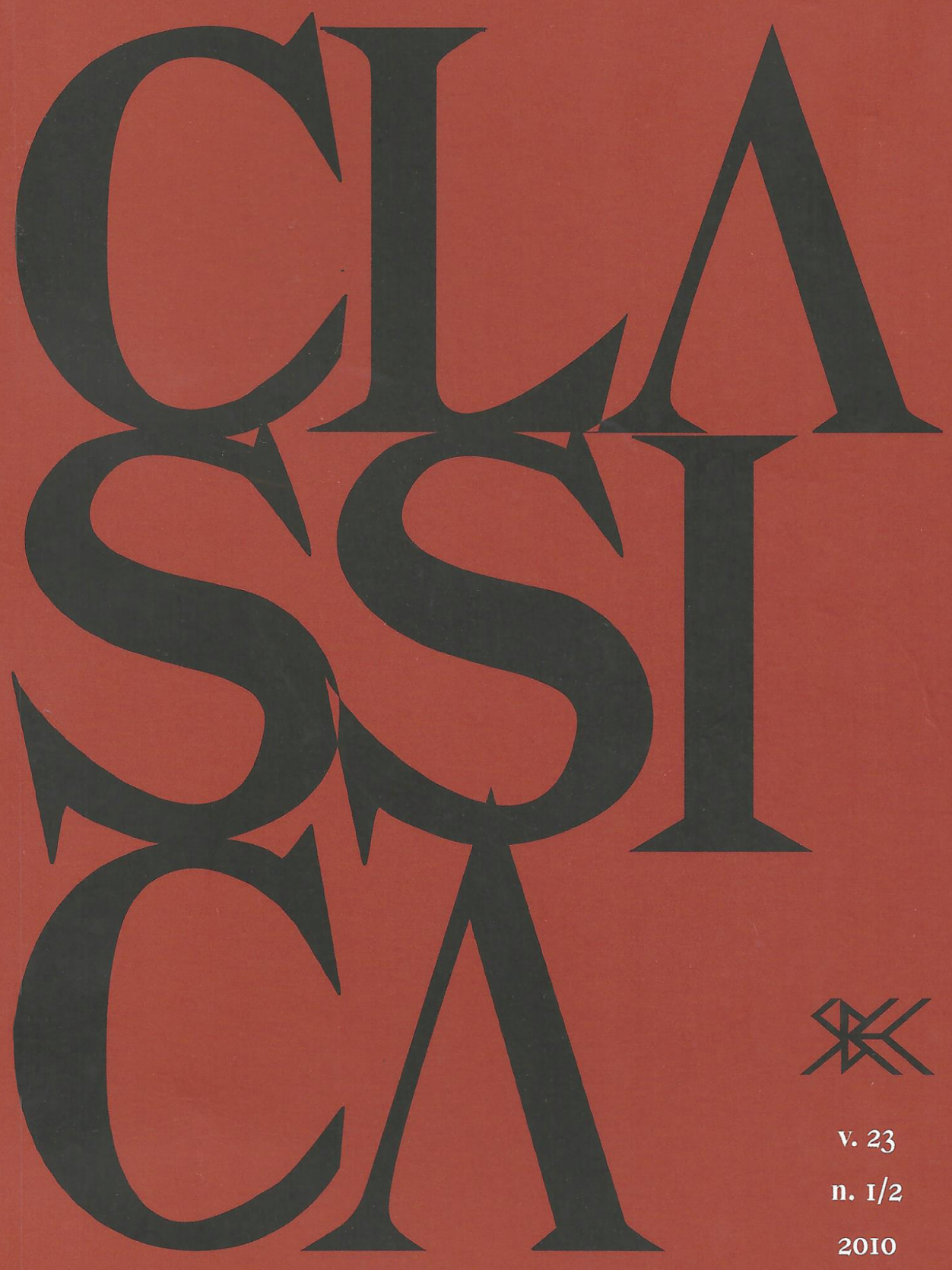




\title{
New evidence for the completeness of the Cleitophon from Plato's musical symbolism
}

\author{
JAY KENNEDY \\ University of Manchester \\ England
}

\begin{abstract}
The evidence and arguments for a system of musical symbols in Plato's dialogues presented in Kennedy's 2011 The Musical Structure of Plato's Dialogues is here extended by showing that the Cleitophon has the same structure. Although this short dialogue is often thought a mere fragment and incomplete, it is shown here that it contains the complete musical structure and so is complete. This settles a longstanding, scholarly debate.
\end{abstract}

Keywords. Plato; Cleitophon; music; symbolism; allegory.

The Cleitophon, a short study of philosophical protreptics, was included in ancient editions of the Platonic corpus. Since it is only five Stephanus pages long, it has, as S.R. Slings' Cambridge commentary shows, often been considered an unfinished fragment or abandoned draft, in part because the dialogue ends abruptly after a sharp and unanswered attack upon Socrates. ${ }^{1}$ The recognition that Plato's genuine dialogues all contain a series of symbols representing a musical scale makes it possible to settle this long-standing question in Plato studies. This essay aims to establish that the Cleitophon contains the same twelve-note scale that organizes all of Plato's genuine dialogues and is thus complete.

The evidence for Plato's musical symbolism was first reported in Apeiron and then expanded many times in The Musical Structure of

Email: jay.kennedy@manchester.ac.uk

Centre for the History of Science, Technology, and Medicine.

Thanks to those who attended my lectures and debated these issues at the departments of classics at Manchester University and Leeds University, the Institute for Classical Studies at the University of London, the Classical Association Annual Conference at Durham University, the University of Brasilia, the Brazilian Society for the Study of Classics, and the Society for Ancient Greek Philosophy at Fordham University. Thanks especially to Professors Gabriele Cornelli and Henrique Cairus for their kind invitations. Translations throughout are my own.

${ }^{1}$ S.R. SuIngs, Plato: Clitophon, Cambridge, Cambridge University Press, 1999. 
Plato's Dialogues. ${ }^{2}$ Classicists, philosophers, and musicologists are now preparing a volume of essays, Plato and Pythagoras: Debating Plato's Musical Symbolism. ${ }^{3}$ After briefly introducing the scheme of Plato's symbolism, this essay first verifies the presence of the Cleitophon's musical structure by collecting together strong and direct evidence and then proceeds to explicate its entire sequence of symbols. The final sections review the several lines of arguments for the dialogue's completeness, but have larger ambitions. The brevity of the Cleitophon makes it an ideal test case for corroborating the earlier analyses of the Symposium and Euthyphro. The methods developed to excavate and exhibit their musical scales apply equally well here. This leads, moreover, to a range of new insights into the narrative structure and philosophical interpretation of the Cleitophon.

\section{Introducing Plato's Musical Symbolism}

It is not possible here to review the several lines of reinforcing evidence for Plato's symbolism or their historical context within the Pythagorean tradition of music theory and symbolism. Instead, a few, key musical ideas needed for the following arguments about the Cleitophon are briefly introduced here.

Twelve-Note Scale. Plato gave each of his dialogues a form by inserting a series of twelve symbolic passages at regular intervals to represent a musical scale with twelve notes $(1,2,3, \ldots 12){ }^{4}$ This scale was well-known in the treatises on music theory that survive from antiquity and is a natural development of basic, Pythagorean music theory (as Theon of Smyrna explicitly shows).

Relative Consonance. The Pythagoreans famously discovered that two notes harmonize when the lengths of the strings that produce them are related by small whole-number ratios. They also developed algorithms for measuring the relative consonance of various pairs of notes. ${ }^{5}$ Two notes an

\footnotetext{
2 J.B. Kennedy, The Musical Structure of Plato's Dialogues, Durham, Acumen Publishing Ltd., 2011. See also J.B. Kennedy, Plato's Forms, Pythagorean Mathematics, and Stichometry, Apeiron: a journal for science and technology, 43.1, 1-32, 2010.

${ }^{3}$ Forthcoming, Acumen Publishing, Ltd.

${ }^{4}$ The 'scale' is known technically as a 'division of the canon'. Plato's scale is given explicitly in ancient music theoretical treatises by Theon of Smyrna and others. See A. BARKER, Three Approaches to Canonic Division, Apeiron, 24.4, 49-83, 1991.

${ }^{5}$ A. BArker, 'Pythagoreans, Ptolemy, and Porphyry on mathematics and the musical concords', forthcoming in Plato and Pythagoras: Debating Plato's Musical Structure, Acumen Publishing, Ltd.
} 
octave apart, for example, are the most consonant. When sounded together with the twelfth note, the notes in the scale that form nice ratios with twelve are, accordingly, more consonant: 3, 4, 6, 8, and 9. The notes that form awkward ratios with twelve are more dissonant: 5, 7, 10, and 11. Other notes like 1 and 2 are relatively neutral. A remarkable feature of Plato's symbolism is that the content of the symbolic passages is correlated with the relative consonance of the underlying notes. That is, passages about the good, virtue, and friendship tend to sit on consonant notes while passages about evil, vice, and conflict tend to sit on dissonant notes, as will be shown below.

Quarternotes. From the classical period through late antiquity, there was a debate about how finely musical scales should be divided. A common answer was that the intervals between the notes should be sub-divided into four, smaller intervals separated by 'quarternotes'. This debate is mentioned in Plato's Republic, Aristotle's Metaphysics, and in Aristoxenus' Elements of Harmony. ${ }^{6}$ A loose group of music theorists, called the Harmonicists, who were Plato's contemporaries, also used a scale graduated in quarternotes. ' In Plato's dialogues, the symbolic scale is composed of twelve notes but the intervals between them are divided by quarternotes, which are marked by similar symbolic passages.

Stichometry. In order to insert passages at regular intervals to mark the positions of the musical notes, Plato needed some reliable method for measuring distances within his texts. There is an extensive literature in papyrology on the ancient practice of counting the lines on papyrus bookscrolls. ${ }^{8}$ There were many motivations for this, as many as we have for counting the number of pages in a book or the number of words in an essay. Ancient Greeks, for example, paid scribes by the line and recorded the total number of lines of literary compositions on the tags fixed to each scroll as a check on their completeness. There is strong evidence that Plato allotted the various arguments or episodes in his dialogues a certain number of lines and counted lines as he composed.

Methodology: accuracy, controls, and falsifiability. Since extraordinary claims require extraordinary evidence, much of the earlier work was devoted to first establishing the presence of the dialogues' stichometric structure with objective and easily verifiable evidence. A combination of

\footnotetext{
${ }^{6}$ The references for this review section may be found in Kennedy, The Musical Structure...

${ }^{7}$ A. BARker, The Science of Harmonics in Ancient Greece, Cambridge University Press, 2007. See also A. BArker, Aristedes Quintilianus and Constructions in Early Music Theory, The Classical Quarterly, 32.1, 184-97, 1982.

${ }^{8}$ K. Oнцу, Stichometrische Untersuchungen, Leipzig, O. Harrassowitz, 1928.
} 
qualitative and approximate evidence together with careful measurements was used. Thus the case does not depend upon achieving any especially high degree of accuracy. Although some measurements are impressively accurate, the qualitative evidence is by itself sufficient to establish the bare fact of the underlying structure. Among a number of controls and checks, it was shown that about half of the 'spuria' included in the Platonic corpus do not have a detectable, stichometric structure. Thus the methods employed here are 'falsifiable' in Popper's sense.'

\section{Strong Evidence}

To show that the Cleitophon is complete it is sufficient to show that it has the twelve-note structure. This section surveys some strong, simple, and direct evidence. In particular, the following depends only upon the idea that locations within the text corresponding to small whole number ratios are marked in special ways. Thus the presence of some mathematical and musical structure can be verified without explicating the entire musical scale.

Later sections will argue that all the musical notes are marked by concepts related to protreptics, the exhortation to become virtuous or study philosophy. This section aims only to show that musically significant locations in the text are marked in striking or particularly emphatic ways.

The Musical Structure of Plato's Dialogues pursued a similar strategy. Thus, in the Symposium, for example, the vision of the form of Beauty atop Diotima's ladder culminated at the ninth note, three-quarters of the way through the dialogue. In the Euthyphro, the only definition of holiness offered by Socrates is located at the ninth note. The following confirms that simple and direct evidence for the embedded musical scale can be found by examining a few key locations.

More Consonant Notes. Within the twelve-note scale, the sixth, eighth and the ninth notes are the most consonant. They are, respectively, one-half, two-thirds and three-quarters of the way through the text of the Cleitophon.

The passage at the midpoint, halfway through the text, contains the central, protreptic theme of the dialogue, namely how to exhort a beginner to turn toward philosophy, the practice and pursuit of the virtue Justice: 'How do we say it is necessary to begin the study of Justice (archesthai ... dikaiosunês péri mathêseôs)? As when, if someone exhorted (proutrepen) \{Note $6.0=408 \mathrm{e} 3\}$ us to train diligently (epimeleian) ...' Strikingly, the word proutrepen, the principal concept of the dialogue, occurs at the sixth note,

\footnotetext{
${ }^{9}$ Kennedy, The Musical Structure..., 59-60.
} 
the calculated center of the text. Other related, key Platonic concepts cluster around it: learning, diligence in training, and Justice (as discussed below, protreptics turns out just to be justice). By itself this cluster of terms may, of course, be a coincidence but the other consonant notes are similarly marked.

The passage at the eighth and next consonant note is marked by some of the leading concepts in Platonism: ' ... each technê \{Note 8.0 = 409c6\} will announce its characteristic (product, to idion ... ergon). For example, the builder's craft will announce the Good, the Beautiful, and the Right (to eu, to kalôs, to deontôs) ...'

This striking correlation between the location of the eighth note and 'the Good, the Beautiful, and the Right' stands out even more clearly when read in context, and is already prima facie evidence for some sort of mathematical or musical structure. The term at the note is technê and we will see below that protreptics itself is a techne that essentially strives toward the Good.

The passage at the location of the ninth note is where the interlocutor boldly defines the philia that is the product or ergon of justice (i.e., the product of protreptics):

The Real and True Love (ontôs kai alêthôs philian) is most indubitably Oneness of Mind (homonoia). Upon being asked $\{$ Note $9.0=409 \mathrm{e} 5\}$ if he would say Oneness of Mind is oneness of opinion or of knowledge, he disparaged oneness of opinion.

Homonoia is also a leading feature of the harmonious city described at 432a7 in the Republic. ${ }^{10}$ Thus, here again, strikingly Platonic concepts are lodged at consonant notes.

The fact that the sixth, eighth, and ninth notes are marked by leading concepts like protreptics, the Good, and Homonoia may be a coincidence. Such terms, after all, occur frequently in the dialogues. To eliminate this possibility, more evidence of the correspondence between symbolic passages and musical consonance is needed. Next, as a contrast, the passages at dissonant notes are shown to be marked negatively, by contradiction and conflict.

Dissonant Notes. The tenth and eleventh notes are the most dissonant in the scale. The eleventh is a particularly clear case Plato's tendency to mark dissonant notes with passages about conflict or breakdowns in relationships, i.e., just the opposite of the love and homonoia that mark the consonant

${ }^{10}$ R. Kamtekar, 'What's the Good of Agreeing? Homonoia in Platonic Politics', Oxford Studies in Ancient Philosophy, Summer, 2004. 
notes. The eleventh note is the dramatic climax of the dialogue. There, Cleitophon finishes his complaint against Socrates and announces that he will no longer be his student - unless Socrates stops merely exhorting him and starts sharing more advanced knowledge. After breaking with Socrates, Cleitophon will study with the sophist Thrasymachus, who notoriously defends the view that 'might makes right' in the first book of the Republic:

On account of this, I think I will go to Thrasymachus and wherever else I can with my perplexity (aporia). Unless $\{$ Note $11.0=410 \mathrm{c} 8\}$ you wish to desist forthwith from exhorting me with these arguments...

This passage is a striking parallel to the eleventh note in the Symposium at which Socrates rejects Alcibiades' advances. Just as here, Alcibiades feels aporia, anger, and considers breaking off his relationship with Socrates. ${ }^{11}$ Thus in both dialogues the musically dissonant, eleventh note is marked by dissonance and acrimony between Socrates and his student. This is in sharp contrast to the unity of the Form of Beauty or the Oneness of Mind which respectively marked the consonant, ninth notes of the Symposium and Cleitophon.

The tenth note in the Cleitophon is marked by a peculiar and confusing passage. Cleitophon claims to have asked Socrates directly about the nature of justice and received conflicting answers:

In the end, Socrates, I even questioned you yourself, and you said to me that it was of Justice to harm enemies and do good to friends. $\{$ Note $10.0=410 \mathrm{~b} 1\}$ But later it appeared that the just man never ever does any harm: everything he does is for the benefit of all.

It is not clear here whether Cleitophon had misunderstood Socrates or whether Socrates had been deliberately misleading. It is clear that the two answers are contradictory. It is, moreover, clear that they were perceived so negatively by Cleitophon that he proceeded to give up his studies with Socrates and turn next toward insulting him. However this passage is finally interpreted, the confusion and contradiction is an appropriate marker for the location of a dissonant note.

Consonant and Dissonant Ranges. Comparing large numbers of Plato dialogues shows that the long stretches of text between the more consonant notes tend to be marked by various kinds of harmony: progress in arguments, cooperation, good humored banter. Similarly, the text between

${ }^{11}$ Kennedy, The Musical Structure..., 168-9. 
the more dissonant notes tends to be marked by disharmony: refutations (elenchus), perplexity (aporia), and bickering or insults. The Cleitophon provides particularly clear and compact evidence for this correlation between broader features of the narrative and the underlying musical scale.

The preceding, two quotations are sufficient to show that the whole section from the tenth to the eleventh notes is the most acrimonious in this short dialogue. Cleitophon there breaks off his relationship with Socrates and rather insultingly doubts that he has any wisdom to share.

The section between the very consonant eighth and ninth notes in the dialogues is often marked by philosophical progress. Here, Cleitophon poses a question at the eighth note, 'what is the product (ergon) of Justice?' At note 8.1 (409d3), a clever companion of Socrates undertakes to answer, and so becomes Cleitophon's dialectical partner. The next twelfth of the dialogue (from 8.1 to $9.1,409 \mathrm{~d} 3$ to $409 \mathrm{e} 8$ ) is the only genuine case in the Cleitophon of progress through a cooperative series of questions and answers. In short, Plato has lodged an instance of that highest of Platonic sciences, dialectics, in the most consonant range of the dialogue. Here too, intellectual harmony tends to dominate in musically consonant ranges. ${ }^{12}$

Narrative Structure. Plato uses the musical scale as a kind of outline for the dialogue. Arguments and episodes tend to fill one or more quarterintervals or even whole twelfths. This broad relation to narrative structure is more difficult to see in this dense and concise dialogue, where sentences may stretch beyond a quarter-interval, but there are some clear instances.

The conclusion of an argument (logos) attributed to Socrates is lodged at the third whole note. Since it is a very consonant note, the conclusion is a strong affirmation of protreptics:

Thus, in every way, the argument (logos) proves that to commit an injustice is involuntary, and it is necessary for every man privately and all the cities together $\{$ Note $3.0=407 \mathrm{e}\}$ to be more diligent about virtue (epimeleia) than now.

In the next sentence, Cleitophon begins to rehearse a new argument, and that in turn continues until the fourth note: 'And so concludes (teleuta) this $\{$ Note $4.0=408 \mathrm{a} 5\}$ argument (logos) of yours ...' Thus both the third and the fourth notes are marked by the conclusions of arguments and the single, extended argument between them fills one-twelfth of the dialogue.

${ }^{12}$ Things turn negative at note 9.2, where there is a final elenchus or aporia. But this note generally is the transition from the 8-9 consonant region to the 9-10 dissonant region. 


\section{Parallel Narratives: a New Argument for Completeness Independent of Musical Structure}

Another way to confirm that the Cleitophon is complete is to exhibit extensive parallels between its narrative and that of another dialogue that is generally considered complete. The evidence below shows that the same philosophical issues shape the narrative structure of both the Euthyphro and the Cleitophon. Although the Euthyphro ends aporetically, it is considered complete. Since the Cleitophon follows a parallel trajectory, it is no less so.

In essence, the denouements of both dialogues centers on a failed attempt to find the concrete product or ergon of Justice. Although Socrates does not interrogate Cleitophon and lead him to a typical elenchus, the final arguments of both dialogues follow a remarkably similar path to their aporetic conclusions.

These parallel narratives provide an argument for the completeness of the Cleitophon independent of its stichometric structure. However, since all the genuine dialogues have the same musical structure and proceed through a similar series of more and less consonant stages, investigations of the parallels between their narratives will reveal much about Plato's methods, as The Musical Structure of Plato Dialogues argued at length.

For clarity, the steps in the argument are briefly summarised here. Not all these steps occur in the same order in both dialogues, although three of the steps are at approximately parallel locations. Despite the differences, it is clear that the same narrative concludes both dialogues:

a) Both Cleitophon and Euthyphro agree they are investigating Justice, which is a technê. For Cleitophon, exhorting students leads on next to the practice of Justice as technê (408e3 ff.); Euthyphro agrees with Socrates that piety is a species of Justice and is similar to technai like dog-training and house-building (12d $3 \mathrm{ff}$.).

b) Both Cleitophon and Euthyphro agree that Justice should have some concrete ergon (409b4 ff., $13 \mathrm{el} \mathrm{ff}$.).

c) In both dialogues confusion about the ergon leads to acrimony between the interlocutor and Socrates (in parallel at note 9.3= 13c7, 410a5).

d) Both Cleitophon and Euthyphro believe that higher technê should have concrete erga because of craft analogies made with medicine and building (409a7 ff., 13e1 ff.).

e) In both dialogues, frustration over the question of erga leads to accusations of reserving or hiding the truth (nearly in parallel about note $10.2=14 \mathrm{~b} 8,410 \mathrm{c} 1)$. 
f) In both dialogues, the failure to find concrete erga of the higher technê leads to the breakdown that ends the conversations (in parallel at note $11.0=14 \mathrm{e} 8,410 \mathrm{c} 8)$.

g) In the final lines of both dialogues, the breakdown is an obstacle to leading the virtuous life.

These parallels are surprising because they show that Cleitophon follows the same path toward elenchus as Euthyphro. Contrary to the common view, they show that the lack of a formal rebuttal by Socrates in the Cleitophon is no grounds for considering the dialogue incomplete. Conceptually both dialogues reach the same conclusion by the same path: they seek the technê of Justice and fail to find its erga.

The Musical Structure of Plato's Dialogues argued that the Euthyphro's debate over the relation of piety to the technical crafts could only be understood in light of Plato's important distinction between higher and lower technai. Although the nature of technê for Plato has often been debated, several of the dialogues contend, as Dodd's brief survey shows, that only vulgar, lower arts produce visible and concrete effects $(\operatorname{erg} a){ }^{13}$ In contrast, the Charmides, for example, compares the virtue sôphrosunê to a higher art without erga (165d8 ff.). Euthyphro makes a fundamental mistake by supposing that piety, which he agrees is a species of the virtue justice, is the sort of techne that produces erga in the same way as the lower arts. This marks him out as a philosophical philistine who cannot appreciate that the higher arts have their effects behind sensible appearances. Arguably, Cleitophon makes the same mistake. His assumption that Justice will have concrete end-products leads to a parallel aporia.

\section{The System of the Cleitophon's Symbolism}

The above evidence is powerfully deepened, developed, and confirmed by placing it within a systematic reading of all the passages marking the musical notes. Excavating the complete musical scale is yet another way of showing the Cleitophon is complete.

The gateway to Plato's symbolism is the theory of forms. As The Musical Structure of Plato's Dialogues explains, Plato marks the notes within a dialogue with references to the many species of an over-arching genus. In the Symposium, for example, passages about various species of 'harmony' in the broad Greek sense (fitting together, blending, musical

${ }^{13}$ For some examples, see Plt. 258d4 ff., Grg. 449d8 ff., and Phlb. 55d1 ff. For an overview see E.R. Dodds, Plato: Gorgias, Oxford, University Press, 196 ff., 1990. 
harmony, etc.) were lodged at the locations of the musical notes..$^{14}$ Recognizing the regular pattern of the notes in a dialogue, therefore, requires the reader to recognize a Platonic form, i.e., that the many species share a common element and are therefore similar. These similarity relations lie beneath or behind the apparent surface of the narrative and constitute the musical scale. Plato organizes and unites each dialogue by giving it a form.

Typically, each of Plato's dialogues more or less explicitly discusses the genus of the concepts that mark its notes. Thus, in the Symposium, Eryximachus exposits an explicit theory of the genus of harmony in music and other fields $(3.2=187 \mathrm{c} 8)$. In the Cleitophon, perhaps not surprisingly, the over-arching genus of concepts is 'protreptics', i.e., the process of turning students toward the pursuit of virtue. The word protrope occurs at the calculated centre of the dialogue at note $6.0(408 \mathrm{e} 3)$.

The Cleitophon explicitly connects the concept of protreptics to music and thus makes this genus an appropriate concept for marking its notes. In short, philosophical protreptics is an 'attunement' in virtue and especially in the political virtue of justice. The key passage occurs early in the dialogue, and contrasts a lack of attunement in politics and in ordinary music. It is the lack of political and not musical harmony that leads to the horrors of war:

... on account of being $\{$ Note $2.1=407 \mathrm{c} 6\}$ out of tune (plêmmeleian) and careless - but not on account of a lack of rhythm in your foot [beating time] for a lyre - brother behaves to brother and cities behave to cities without rhythm and disharmoniously. There is political dissidence (stasis) and in war they do and \{Note $2.2=407 \mathrm{~d} 2\}$ suffer the worst. ${ }^{15}$

Thus education in virtue or the pursuit of philosophy is a kind of superior music or harmonization.

The Cleitophon also makes politics the technê of protreptics (4.2 $=408 \mathrm{~b} 5$ ), which establishes the association needed here: protreptics is politics and politics is an attunement. These passages therefore make protreptics an appropriate concept for marking musical notes.

Allegorists generally aim at a peculiar balance between concealment and communication. Since Plato's forms should lie behind appearances, the similarities between the symbolic passages that constitute his musical form cannot be too obvious. The dialogues therefore adopt a two-fold strategy. They use superficially dissimilar concepts to mark the notes, but

${ }^{14}$ Kennedy, The Musical Structure...

${ }^{15}$ These musical notes are somewhat dissonant and so are marked by failures of protreptics or attunement. 
then in passing carefully connect them to the central genus. In short, the dialogues contain explicit 'clues' to the relations between the concepts that mark the notes.

The opening notes in the Cleitophon are a good example of this technique. They are all marked by instances of logoi, i.e, of speech-making or philosophical conversation. That is, the first four notes are marked by the concepts of 'recounting', 'reminding of logoi', 'narrating', and 'frank talk'. These are not obviously species of protreptics.

Later in the dialogue, however, Cleitophon challenges Socrates to stop making mere 'protreptic speeches' (logôn tôn protreptikôn, $11.0=$ 410c8). This clue makes explicit what is, after all, well-known: that talk and speeches are the main weapon of Socratic protreptics. Moreover, the speeches that open the Cleitophon are arguably all in fact protreptic. Thus, quite naturally, protreptic logoi are in this dialogue a species of protreptic education and so references to such logoi are suited to mark the first notes in the musical scale. The dialogue makes explicit the connections between this species (logoi) and the over-arching genus of protreptics.

These clues to the connections between the species are a control on the methodology used below. The best argument that a concept is a species of the over-arching genus of markers is that the dialogue itself says so explicitly. In addition to logoi, the following species mark notes in the Cleitophon:

Protreptics. As mentioned above, explicit mentions of protropê and its cognates mark a few notes.

Education, Teaching, Learning, Study. Many notes are marked by concepts related to education and thus have a clear relation to protreptics. The entire passage at the centre of the dialogue asks, again, how we must 'begin the study of Justice? As when, if someone exhorted \{Note $6.0=408 \mathrm{e} 3\}$ us to pay attention (epimeleian) to the body ...'

Diligence in Study, Training. Many notes are marked by epimeleia and its cognates. Diligence or care is essential to protreptic education. Thus the first, very harmonious note, 3.0 , is marked by '.. it is necessary for every man privately and all the cities together $\{$ Note $3.0=$ $407 \mathrm{e} 1\}$ to be more diligent (epimeleia) than now.' The word epimeleia has the root ' $m e l$ ' and is an apparent cognate of the Greek word for 'melody'. This musical association may account for Plato's frequent use of epimeleia as a marker in the Cleitophon and other dialogues. ${ }^{17}$

${ }^{16}$ Recounting $(0.0=406 \mathrm{a} 1$, diêgeito $)$, reminding of talks $(0.1=406 \mathrm{a} 5$, apomnêmoneue ... logous $)$, narrating $(0.2=406 \mathrm{a} 9$, diexelthoimi $)$, and free-speech $(0.3=406 \mathrm{a} 10$, parrêsian $)$.

${ }^{17}$ Kennedy, The Musical Structure..., 69. 
Method of Questions. Explicit references to 'questioning' mark several notes. Cleitophon says that he will 'in Socrates' way' question Socrates' followers (408d1, after 5.1), and this makes it clear that dialectical questioning is a kind of protreptics. Question and answer pairs mark several notes later in the dialogue: 'Upon being asked \{Note 9.0 = $409 \mathrm{e} 5\}$ if he would say oneness of mind is oneness of opinion or of knowledge, he disparaged oneness of opinion.'

Aversion and Adversion Trope. Turning away from vice and toward virtue is the essence of protreptics. Etymologically, the word 'protreptics' means 'turning toward or forward'. Socrates, for example, rather brusquely marks the first note by saying he will follow Cleitophon's advice: '... since it's clear you know how I can be worse and better, I will in part practice and pursue [the better] and in part flee $\{$ Note $1.0=407 \mathrm{a} 3\}$ the worse with all my strength.' References to praise and criticism are a variation of this trope, and mark several notes: 11.3 (= 410e4), etc.

Politics, Judging and Justice. The Cleitophon takes a large view of protreptics. It is not merely exhorting youths toward virtue, but is identical with politics, judging, and justice itself. These connections are made explicit in several passages. For example, '... the craft of steering humans, which you, Socrates, often name the craft of politics, saying that it is the same as Justice and the Note $4.2=408 \mathrm{~b} 5\}$ craft of judging.' Cleitophon later concedes that 'justice' is a technê that produces just people, (note $7.2=409 \mathrm{~b} 7$ ) and so in this dialogue the practice of the virtue justice is essentially protretpic.

Love and Homonoia. The idea here seems to be that protreptics produces love and oneness of mind: 'love is entirely good and a product (ergon) of $\{$ Note $9.1=409 \mathrm{e} 8\}$ Justice, it is the same as oneness of mind ...'

Dissonant Notes: Neglect, Carelessness, Failure of Protreptics. A number of notes are marked by failures of protreptics, as in the breakdown of the relation between Socrates and Cleitophon at note 11.0 (discussed above).

Several lines of evidence for the presence of the 12-note musical structure in the Cleitophon have been established:

- Consonant notes are marked with goodness, truth, etc.; dissonant notes with contradiction and conflict

- Ranges of notes are marked in ways the correspond with the relative consonance of the surrounding notes 
- The narrative structure is correlated with the musical structure: arguments end at major notes, etc.

- Protreptics is, for Plato, akin to 'attunement' and so is a musical concept appropriate for marking musical notes.

- The locations of the musical notes within the symbolic scale are marked with species of protreptics.

Since it contains the complete 12-note scale, this dialogue is complete.

Moreover, these parallels deepen the philosophical interpretation of the Cleitophon in several ways. First, the Cleitophon has now been shown, despite its brevity, to be a conceptual whole. Although Cleitophon carries on his conversations with several different interlocutors, the argument proceeds to a conclusion as satisfying as that of the Euthyphro. Both dialogues establish that the desired craft is a kind of justice, and both end in puzzles about its end-products (its erga). Second, this comparison reveals a key difference between the two dialogues. In the Socratic dialogues, the young interlocutors typically take a stand and have their own confusions exposed. By assenting to the elenchus, the youths discover an inadequacy within their own souls. This internal disquiet produces the sting that turns students toward philosophy. In contrast, Cleitophon tests others' ideas. His dissatisfaction is directed outwards toward his teachers and peers. This kind of elenchus is eristical and produces a sophistical conceit.

A complete commentary on the passages marking all the musical notes in the Cleitophon has been completed, and shows that the scheme for marking the notes, introduced here, is carried out consistently through the entire dialogue. ${ }^{18}$

Título. Novas evidências a favor da integralidade do Clítofon com base no simbolismo musical de Platão

Resumo. As evidências e os argumentos para um sistema de símbolos musicais nos diálogos platônicos apresentados em "A estrutura musical dos diálogos de Platão" (Kennedy, 2011) são aqui estendidos, a fim de mostrar que o Clítofon apresenta mesma estrutura. Embora este curto diálogo seja frequentemente considerado um mero fragmento e incompleto, mostra-se aqui que ele contém estrutura musical completa, sendo, então, completo. Encerra-se, dessa forma, um longo debate acadêmico.

Palavras-chave. Platão; Clitofon; música; simbolismo; alegoria.

${ }^{18}$ Available on request. 